\title{
Effects of Islamic Banking on Financial Deepening Amongst Muslims Case Study Robe Town
}

\author{
Fedli Muhammed (Fedli Muhammed) \\ School of Business and Economics Rift Valley University, PO box 55, Bale Robe, Ethiopia
}

\begin{abstract}
This study assesses the effects of Islamic banking on financial deepening amongst Muslims case study Robe town. To do so, descriptive research design and simple random sampling technique were employed to examine a sample of 384 interested population in the Islamic field was visited from the population of over 100,000 and questionnaires were used as primary data collection instrument. The target population for this study was the Muslims society. The research study indicates that the most popular financial service in the study area was murabah while musharak has complexity regulation in Islamic banking operation. The study identified that government policies and regulations affect the financial service provided by Islamic banking. The customers encounter problems of raising capital, accessing finance and accessing credit. The study recommends that there should be amendment of banking regulation to facilitate loan for government employee, increased support for learning visits to improve the information flow, the government should come up with policies on training of business owners and managers especially on directing, staffing, deployment of finance resources and controlling activities, the government should seek to address the significant issues like regulation of financial service that has impeded economic development Islamic banking system in the country.
\end{abstract}

Keywords: Islamic bank, financial deepening, Robe town

DOI: $10.7176 / \mathrm{JPCR} / 52-01$

Publication date: February $28^{\text {th }} 2021$

\section{Introduction}

\subsection{Background of the study}

Finance as defined by different scholar it is creating, moving and using money, enabling the flow of money through a company in much the same way it facilitates global money flow were as financial deepening is refers to increased provision of financial services such as safe keeping, transferring, saving or loan and insurance with a wider choice of services geared to all levels of society in the area.

Financial deepening is the ability of financial institutions in an economy to effectively mobilize savings for investment purposes. Financial deepening vigorously attracts the reservoir of savings and idle funds and allocates same to entrepreneurs, business, households and government for investments projects and other purposes with a view of returns which forms the basis for economic growth Nzotta and Okereke (2009).

Financial deepening plays an important role in determining the growth of bank service. It broadens its resource base, raises the capital needed to stimulate investment through savings and credit, and boost the overall productivity. The design and implementation of effective interventions and programs in the Ethiopia banking sector has led to a continued growth in financial assets, with a direct contribution from financial intermediaries Omer (2016).

Financial deepening provide an increasingly broad range of many financial services, such as fund mobilization, asset allocation, payment and exchange settlement services, and risk transformation and mitigation. These specialized financial intermediaries perform transactions using financial instruments that comply with Shariah principles plays the great important role in reducing risk and vulnerability for disadvantaged groups, and increasing the ability of individuals and households Shaw (1973).

According to Nwanna and Chinwudu (2016) Financial deepening also helps in increasing the provision and choices of financial services.The common Islamic banks' ways of raising revenue as an alternative to interest is through financial intermediation of profit sharing (Mudharabah), joint venture (Musharakah), cost plus (Mudharabah) and leasing (Ijarah) contracts Ariff (1998).

The main reason for emergence of Islamic banks in Ethiopia is the strong demand from a large number of Muslims for Shariah compliant financial services and transactions IsDB Annual report (2019).To satisfy the community that have problem with the current banking system and to provide alternative banking system the NBE was expected to approve a directive that paves the way for the establishment of what was called as the first Islamic bank in Ethiopia. A circulated draft form of the NBE"s directive has allowed Ethiopian nationals to establish full-fledged Islamic financial institution. However, the directive has only opened the door

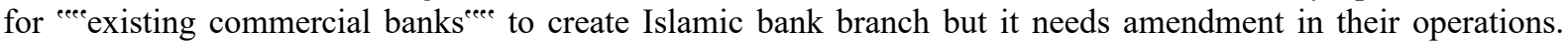
This Come in to force in October 2011, but interest-free banking in Ethiopia started only in September 2013, when the Oromia International Bank S.C launched the service. The Commercial Bank of Ethiopia joined the market at the end of October, followed by United bank S.C, which began providing the service on May 1, 2014. 
The introduction of Islamic banking in Ethiopian banking industry started in 2019 when Hijra Bank launched service in Addis Abebe followed Bilal bank at the beginning of 2020 in Adama and currently Hijar Bank launched service in Robe Town, which has important for being a world class bank, and in addition to provide options for the customers. As the document of Commercial Bank of Ethiopia (June, 2019) indicates that islamic banking financial products and services offered under separate service are Wadiya Amanah account, Qard account, Mudaraba account, $\mathrm{Ba}^{\mathrm{e}} \mathrm{i}$ - Salam mode of financing, Istisna mode of financing, Ijarah mode of financing, Musharakah, Mudarabah, Qard al Hassen and Kafala.

According to policy analysis report (2017) In 2008 E.C, the Ethiopian Banking Business Proclamation $(592 / 2008)$ was amended to include a provision for IFB. In 2011 E.C, the NBE issued a directive to authorize the business of IFB (SSB/51/2011). Know recent Proclamation No: 1159/2019 made the dream of establishing a full-fledged interest-free bank in Ethiopia real. The proclamation was issued after the current Prime Minister Dr, Abiy Ahmed promised to allow the establishment of full-fledged interest-free banking on his speech during the Ramadan Iftar (fast-breaking) program organized by the Ethiopian Islamic Affairs Supreme Council (EIASC) at Millennium Hall on May 22, 2019 (Getachew \& Kedir, 2019).

In Ethiopia, understanding effect of Islamic banking on financial deepening is far more crucial, mainly because Islamic banking service have to compete with the long-established conventional banks in a dual-banking system. The survey research on effect of Islamic banking on financial deepening is timely and very important.

This study is tried to identify the effect of Islamic banking on financial deepening in Ethiopian dual banking system in Robe Town.

\subsection{Statement of the problem}

Islamic banking is financial institutions that provide financial service or product compliant with religious faith for Muslim society. There are limited banking products available to serve the Muslim community who do not want interest until 2011E.C. Even if the NBE has launched an Islamic bank directive, there is still a need to develop an adequate legal framework to effectively implement and capitalize on a prosperous IB sector in Ethiopia; however, there has been no concrete work conducted for a proper roll out of these products.

Africa Ethiopia report (2020 EST.) the total population estimated nearly 108,113,150 from all total population of the country which is nearly $33.9 \%$ of the population are Muslim, but until 2011 E.C there was no access service for Muslims who wanted to perform their business according to their faith. These factors have consequently in habited a good number of potential customers from doing business with the banks available in the country because those people considered the services offered by the banks as against their religious faith Debebe Alemu (2015).

Most recent studies have focused on the effect of Islamic bank on financial deepening. For instance mustaf (2013) in Kenya, (Naceur, Barajas, and Massara, 2015; Omer 2016) in kenya, Nwanna, Chinyere (2016) in Nigeria.

Mustaf (2013) had done the study on effect of Islamic bank on financial deepening using descriptive research design and sample of 280 from 10000 to achieve the objective. The findings have shown that lack of access to financial information service, Lack of managerial training and experience affect the growth of small and medium financial institutions, government policies and regulations affect the growth of small financial institutions, technological changes affect the growth of the financial institutions and customers encounter problems of raising capital, accessing finance and accessing credit.

The study of (Naceur, Barajas, and Massara, 2015) which was conducted on effect of Islamic bank on financial inclusion by using descriptive research design and sample of 123 from 659 to achieve the objective. the finding have shown that Islamic banking seems to be an effective avenue for financial inclusion, physical access to financial services has grown more rapidly in the countries, the use of these services has not increased as quickly and regression analysis shows evidence of a positive link to credit to households and to firms for financing investment.

As the researcher knowledge there is no study conducted on the relationship between Islamic banking variability and financial Deeping in Ethiopia underexplored. Therefore the researcher initiated to conduct this research to show the effect of Islamic bank on financial deepening to fill the knowledge gap of the above scholars. Since studies conducted by above scholars' in particular area differs from our country in terms of culture, economic activities and banking regulation. The present study, therefore, was proposed with the general objective of assessing the effect of Islamic bank on financial Deepening among Ethiopian Muslim Robe town. However, one of the objectives of this thesis is to establish whether the Shariah-compliant financial products currently on offer in Ethiopia have met the expectations of this community as far as accessing financial products is concerned.

\section{LITERATURE REVIEW}

This chapter reviews previous study and literatures on effect of Islamic banking on financial deepening 
specifically this begin with discussion theoretical literature which include definition of Islamic banking, history of Islamic banking, definition of financial deepening and importance of financial deepening then In Ethiopia in the current tendency followed by pervious empirical literature which were conduct on effect of Islamic banking on financial deepening.

\subsection{Monetary and Macro Theory}

The fact that Islamic banking and finance avoids the use of interest-based lending has significant implications to monetary policy. In managing the money supply, the monetary authority would monitor the real rate of growth and set the rate of monetary expansion to the level consistent with prices stability and expected real growth. Some Islamic economists propose a 100per cent required reserve ratio in order to give the authorities absolute control of the money supply and to appropriate all seignior age resulting from monetary expansion to the government instead of banks' shareholders Al-Jarhi and Mabid Ali (2013).

Profit sharing modes of Islamic finance, focus would be on the profitability and rate of return of the concerned investment. Financial resources would be directed to the most productive investments. This would increase the efficiency of the financing process and also reinforce efficiency in the real sectors. In credit purchase and leasing modes of Islamic finance, money is not given outright, but rather commodities are given in return for debt obligations. Credit expansion in the face of increasing credit-purchase of assets and commodities would be tied directly to higher demand for assets and commodities, which would have a direct bearing on aggregate supply. Consequently, credit finance under Islamic finance would be less inflationary in comparison to conventional banking and finance Mustafa (2013).

Islamic banks aim to have all financial transactions be based on real economic activity; and prohibit investment in sectors such as tobacco, alcohol, gambling and armaments. They provide an increasingly broad range of many financial services, such as fund mobilization, asset allocation, payment and exchange settlement services, and risk transformation and mitigation. These specialized financial intermediaries perform transactions using financial instruments that comply with Shariah principles. The Islamic financial industry is comprised of across-the-board financial institutions including: onshore and offshore commercial banks, non-bank financial companies, housing cooperatives, microfinance institutions, venture capitals, mutual funds, insurance companies, etc. Moreover, there are dedicated regulatory, legal and academic institutions at the international level that are providing support in establishing the IFS. The main reason for emergence of Islamic banks in Ethiopia is the strong demand from a large number of Muslims for Shariah compliant financial services and transactions.

\subsubsection{Behavior of Credit Markets}

An important part of macro theory relates to the behavior of credit markets. In conventional finance, present money is traded against future money either in integrated debt or in bond markets, where huge sums of debt are traded daily. Debt markets act as an easy conduit to move short-term funds from one country to another, more often than not, in reaction to factors that are only nebulously related to economic fundamentals. Such flows threaten the world economy with the spread of instability that might start in one single debt market in a fashion that economists have come to call "contagion."

\subsubsection{Risk-sharing}

Another important aspect of micro theory is that of risk-sharing. Conventional finance can be likened to a spectator's game where few skilled players stay in the playground and a big crowd is watching from outside. Islamic finance, meanwhile, is similar to participatory sports, where everyone is playing and no one is merely watching. In addition, there is a moral side to Islamic finance that seems to be in the back of everyone's mind. Risk is known to be one of the most important ingredients of making investment. In Islamic finance, those who finance investment share a good part of the risk with those who carry out actual investment activities.

Conventional finance leaves risk to be borne by specialists and traded among them. Banks and financial institutions provide investors with loans guaranteed by collateral. In this fashion, they keep themselves shielded from certain kinds of risk, like those attached to production, marketing and distribution, and limit their exposure to risk related to collateral only. Islamic finance allows savers who deposit their funds to share with banks the risks associated with choosing the right investment and how successful it was. Banks and financial institutions advancing funds share risk with those receiving finance, including producers, traders, and the like. Islamic finance with proper corporate governance allows depositors some influence on banks investment decisions..

\subsubsection{Equity Consideration}

An important aspect of macro theory is equity. Islamic financial system is basically viewed as private profitseeking business enterprises that operate according to the market mechanism. By themselves, they cannot reduce, let alone, eradicate poverty. However, if given the right tools, they might contribute to the efforts taken by the whole society in that direction. Zakah proceeds are known to be earmarked for several uses including income and wealth maintenance for the poor. Income maintenance is provided within narrow limits to those incapable of working and wealth maintenance is provided to the rest of the poor. 


\subsection{Banking Theory}

Let us first look at the liabilities of Islamic banks of which only demand deposits, placed on the basis of profit and loss sharing, are guaranteed. When such banks face macroeconomic or bank-specific crises, investment depositors automatically share the risk. The bank is less likely to fall bankrupt as bank run is least probable. It can, therefore, be said that an Islamic banking system is relatively more stable than conventional banking Khan and Mohsin (1986). Banking theory studies finance as a process that runs among three parties: a principal, an agent and an intermediary, where both the principal and the agent jointly finance a project which is managed by the agent and partly financed by the principal Ennis and Huberto (2000).

\subsection{Evolution of Islamic Banking}

The origin of Islamic banking as a major player in the financial domain was in the early $1970^{\circ \mathrm{s}}$. But the rules and regulations governing Islamic banking system has been present in the world for many centuries. During the middle ages, Islamic finance was popular and was widely accepted and practiced. It helped in furthering the trade and business in the Muslim world. The Islamic merchants began to play a very important role in the European region (Mediterranean, Spain and Baltic States). Islamic finance has become a global system spreading as far as Asia, the Middle East, and the Western world. Islamic banking is not limited only to the Muslim nations in the Middle East but also exists in the developed economies such as USA, Europe, and the far East. Today, more than four hundred and fifty (450) Islamic banks are operating from China to USA, having assets in excess of one trillion US dollars.

\subsection{Principles of Islamic Banking Service}

According to Bala et.al, (2009) Islamic Banking finance is based on the themes of community banking, ethical banking, and socially responsible investing. Its goal is to be an ethical, indigenous, and equitable mode of finance. The six key principles that govern interest free are as follows. Freedom from interest /segregation of funds The Quran, the Muslim holy book, expressly forbids Interest, which includes any payment of interest (not only excessive interest) on monetary loans. A loan with a fixed return to the lender regardless of the outcome of the borrower's course of action is viewed as unfair. Interest is also believed to be exploitative and unproductive because it is considered to represent sure gain to the lender without any possibility of loss as well as a reward in return for no work. These factors are believed to lead, in turn, to inflation and unemployment and to stifle the social and infrastructural development of a nation.

\subsection{Islamic Bank provide the following service}

\subsubsection{Interest (Riba)}

Interest is the component in the banking concept. According to Mohammed and Mahdi (2010) interest is one of the most effective factors for deciding to deposit in banking system. Herald and Heiko (2009) also mentioned interest as one of the determining factor for commercial bank deposit and it is important element of Islamic banking economic society. All covers the meaning to load additional money on funds lent to borrower. In addition to this Iqbal and Mirkahor (2011) interest simply refers to the "premium" that must be paid by the borrower to the lender along with the principal amount as a condition for the loan or for an extension in the duration of loan. Interest is a contractual instrument by which the lender collects a predetermined interest added to the principal amount it has lent out. The principal amount can be money, gold, silver, or tangibles including wheat, barley,etc. Qasaymeh (2011)

\subsubsection{Prohibition of interest}

Prohibition of interest is any unjustifiable increase of capital, whether in loans or sales, it is the central tenet of the system. More precisely, any positive, fixed, predetermined rate tied to the maturity and the amount of principal that is, guaranteed regardless of the performance of the investment is considered interest and is prohibited Iqbaland and Mirkahor (2011).

\subsection{Islamic banking models}

\subsubsection{Interest free window service}

According to Juan Sole (2007) an interest free banking window is simply a window with a conventional bank via which customer can conduct business utilizing only sharia compatible instruments. Sanusi (2011) defines interest free banking window as a business model in which conventional banks offer interest free banking products and services from their existing branch network. In short, interest free banking window refers to a situation whereby a conventional banking system provides some of the interest free banking products or services. In other words, it can be seen as a banking system that meets up only the profit, loss, and risk sharing principle of interest free banking for some of its products Audu and Mikailu (2014).

\subsubsection{Subsidiary/branch islamic banking service}

The commercial banking unit, which offers shari'ah compliant products and services only in the specific branch. 
It is a semi-independent office of a bank engaging in banking activities such as accepting deposits or making loans at facilities away from a bank's home office. This branch banking established when the main bank feels there is a potential of concentrated customers are found in the area want to serve these customers.

\subsubsection{Full-fledged Interest free banking service}

Once a conventional bank has operated an Interest free window for some time and has gathered a sizeable customer base for its Interest free banking service activities, it may decide to establish an Interest free subsidiary, or even fully convert into a full-fledged Interest free bank. By following either of these two routes, the bank may benefit from economies of scope and concentration of knowledge and expertise. The bank will be able to offer a wider range of Shariah-compliant banking products than through the Islamic window alone.

\subsection{Uses of financial resources in Islamic Banking}

Financial intermediation is the major function of modern banking system. Financial intermediation means taking funds from people who have more than they need at this juncture in time and providing those funds to persons who need them for their economic transactions and activities Hassen and Lewis (2007:279).

According to Yahiya Abdurahman (2010) Islamic banking pays close attention as to whom and what to finance. (IB) do not finance for example alcohol and gambling related businesses, such as liquor stores or gambling casinos. It also does not finance environmentally irresponsible companies and businesses that are not fair to their employees. IB does not finance speculative activities that are focused on making money out of money, based on speculations in the different financial, commodities, and real estate markets. It is community banking at heart. It believes in community development. It considers its role to be a qualified professional entity that is sound, safe, responsible, and trustworthy to attract the deposits and savings of the community. Abdulrahman (2010:198

\subsubsection{Shareholder Funds}

An Islamic banking may raise an initial equity funds by following the principles of musharaka (equity participation) under this principle, the capital owners enter in to a partnership with the bank by contributing equity in return for a share of banks profit or loss on the basis of predetermined ratio Bala et.al (2009: 23).

\subsubsection{Wadiah saving accounts}

Islamic banking offer saving account with an aim of drawing in and persuading depositors to enjoy this safe keeping facility. Bank customers normally choose saving accounts because of fulfilling precautionary motives Haron and Wan-Azmi, (2008).islamic banking practice the principle of wadia in operating customer saving account. The bank may request permission to use customer funds deposited in these accounts as long as these funds remain within the banks discretion. The situation is very different in the Interest free banks. Here too the depositor's first aim is to keep his savings in safe custody. Interest free banks divide the conventional savings account into two categories. Savings account and investment account.

\subsubsection{Murabah Financing}

Murabah financing is a popular method used by islamic banking to meet short term trade financing needs for its customers. It is often referred to us cost Plus-financing or mark up financing. In this type of financing the bank agrees to fund the purchase of specific asset or goods from a supplier at the request of customers up on acquiring the asset, the bank sells it to the customer at the predetermined mark up.

\subsubsection{Musharakah Financing}

Musharakah is a type of partnership financing in which one of the partners is an islamic banking. Profits and losses are shared on predetermined formula. Profit sharing need not be based on the proportion of the shares owned, but liability of loss is limited to the contributions of the shareholders. In other words, investors cannot be liable for more than the amount of capital they invest in the partnership Shanmugan and Gupta (2007) Musharakah is an Arabic word which means sharing, and relates to the sharing of profits or losses resulting from joint ventures or partnerships.

\subsubsection{Ijarah}

Ijara means to give something on a lent. Under the ijara arrangement the bank purchases a tangible asset based on the clients' specification and leases it to the client. The bank gives the right to use the asset to lessee as well as physical position of the asset. In return the lessee makes rental payments based on the agreed schedule. Up on the expiration of the lease the lessee returns the asset to the bank (lessor). According to Roy (1991:434) Ijara is a source of short or medium-term finance that is used by businesses in fields such as construction, for the financing of heavy machinery or other equipment. The bank purchases goods such as construction equipment and then leases them to the client on a specified sum, fixed-period basis. Monthly payments by the client are fixed at rates which cover all or most of the original purchase price of the item over the period of the contract. A contract can incorporate both Murabaha and Ijaraif the eventual sale to the client is agreed upon at the time the original contract is made.

\subsubsection{Bai'bithmanAjil (BBA)}

Bala et.al (2009: 28) defines bai"bithmanajil is the sale of goods by the bank to a customer on a deferred 
payment basis over a specified period at a price that included a markup or profit margin agreed to by both parties. Bai'bitmanajil plan is commonly used for financing the purchase of real property, vehicle or consumer goods.

\subsubsection{Al-Ijarathumna al bai (AITAB)}

Financing on this modality essentially an ijara (leasing) contract combined with bai-purchase contract. Under the first contract, the purchaser (customer) leases the goods from the owner (the Bank) at an agreed rental price for specified period. Upon expiration of the leasing, the purchaser enters into a second contract to purchase the goods from the owner at an agreed price Bala et al, (2009: 34).

\subsection{Financial Deepening}

The establishment of Islamic banking and microfinance institutions is one of the major highlights in Pakistan's financial sector development in recent years. These specialized institutions are expected to enhance deepening of financial services in the country through offering services to two major segments of the society that had remained outside the coverage of the existing financial system. First, those who are not using the existing system due to its non-conformity with the Islamic rules of law; and second, the poor people, who do not have access to the conventional financial system.1 Both the Islamic banking and microfinance institutions have registered rapid growth during the last couple of years, although they have covered only a small portion of the available market.

According to Fisher (2001) financial deepening refers to the greater financial resource mobilization in the formal financial sector and the ease in liquidity constraints of banks and enlargement of funds available to finance projects

The finance led theory anchors this work, which postulates that (Agu and Chukwu, 2008; Nzotta and Okereke, 2009; Victor and Samuel 2013) defined that Financial deepening means an increase in asset and providing level of financial services to the economy. The total amount of financial assets will constitute an optimal measure of financial deepening.

\subsubsection{Importance of Financial Deepening}

Nwanna and Chinwudu (2016) Financial deepening also helps in increasing the provision and choices of financial services.

According to Jalilian and Kirkpatrick (2005) there are some clear links of financial deepening with Islamic bank in developing country? Empirical analysis confirms the common finding of a positive relationship between financial deepening and Islamic, noticeably for poorer developing countries. Finance as a well established supply leading character .i.e. the level of financial deepening and stock market liquidity each exerts an independent, positive influence on economy growth. Financial services and financial deepening (as measure by the size of the intermediary sector) stimulates economic growth by increasing the rate of capital accumulation and by improving the efficiency with which economies use that capital in the current period as well as in the future.

Financial deepening can also lead to greater efficiency of financial intermediation (e.g. via intermediation of greater amounts of domestic savings and investment cycles) and thereby greater stability. The diversified funding base of financial institutions has played a role in cushioning the impact of a global credit (wholesale funding) crunch on domestic financial intermediation Sahoo (2013).

Financial deepening plays an important role in reducing risk and vulnerability for disadvantaged groups, and increasing the ability of individuals and households Shaw (1973). Direct access to financial services can improve individual livelihoods amongst the poor by enabling them to manage scarce resources more efficiently, thereby smoothing consumption and protecting against economic shocks.

\subsection{Opportunities to Islamic banking}

Islamic banking operation now exists in about 100 countries worldwide and is said to be growing at $10-15 \%$ a year. In Africa, with a well over $40 \%$ of the population constituting Muslim society, the islamic banking business has spread out quiet quickly as the target community eagerly awaited its introduction into the markets NIB (2015).

According to Nuri Hussein, the acting director of the OIB, islamic banking department the newlyintroduced Islamic banking is booming in Christian-majority Ethiopia. OIB managed to mobilize 300 million Birr within two months, have more than 4,000 customers, who have deposited in the Islamic banking program and Customers are now depositing on average 2-2.5 million Birr on daily basis (DireTube.com).

\subsection{Challenges Faced By Islamic Banking}

In islamic banking system there is a serious shortage of scholars and qualified managers. Unfortunately the managers are not well trained in the use of islamic banking financial practices. Islamic banking in western countries especially in UK is facing the problem of legal system because Islamic banking not yet proper regulated due to this there is possibility to create tension between Islamic banking and regulators. It is fact that islamic banking is not well regulated at the moment because they have not a strong branch network. Islamic bank of Britain has only eight branches around the UK (www.islamic-bank.com). 


\subsection{Empirical Evidences}

\subsubsection{Empirical Evidences General Review}

The study of Mustaf (2013) which was conducted in kenya the study on effect of Islamic bank on financial deepening using descriptive research design and sample of 280 from 10000 to achieve the objective. The findings have shown that lack of access to financial information service, Lack of managerial training and experience affect the growth of small and medium financial institutions, government policies and regulations affect the growth of small financial institutions, technological changes affect the growth of the financial institutions and customers encounter problems of raising capital, accessing finance and accessing credit. The study of Naceur, Barajas and Massara (2015) which was conducted on effect of Islamic bank on financial inclusion by using descriptive research design and sample of 123 from 659 to achieve the objective. the finding have shown that Islamic banking seems to be an effective avenue for financial inclusion, physical access to financial services has grown more rapidly in the countries, the use of these services has not increased as quickly and regression analysis shows evidence of a positive link to credit to households and to firms for financing investment.

According to Macy (2016) study in Pakistan institutions helped in the deepening of the financial sector by offering services to the un-banked segments of the society. Although at present both the sectors are at the very initial stages and capturing a very small portion of the available market, their momentous growth indicates a great potential of these sectors to be the essential parts of the financial system of the economy in coming years. The Islamic banks are enjoying a relatively better financial health than the overall banking industry (on average).

\subsubsection{Empirical Evidences In Ethiopian Context}

In Ethiopia, IB is a recent phenomenon. As a result, there is no empirical literature on effect of Islamic banking on financial deepening in the area as researcher knowledge.

\subsubsection{Status of Islamic Banking in Ethiopia}

Islamic banking is at an introduction stage. The existing legal framework does not permit full-fledged Islamic Banking. It need to be carried out in the prevalent legal set up while appropriate models need to be selected and implemented to suit society's diverse financial needs. To accommodate Muslims, who are by Sharia'h - Islamic law - prohibited from taking or giving interest (riba), commercial banks are currently offering zero interest and alert to increase financial service. The expansion starting from Addis (Bilal bank) extended to different region of the country including nur Islamic bank (convectional bank) in Robe town and Hijar Bank launched service currently which is different from Islamic bank expanded by convectional bank.

\subsection{Summary of Literature Review}

Prior studies have sought to establish that Islamic banking is an appearance of practical terms and application of part of Islamic regime conduct that encompass every area of the economy, honesty, social and private lives. Absence of Islamic finance in an Islamic society is a reflection of an imperfect carrying out of Muslim duty unto the massive who had described a religion for Muslims that is economically related as well.

According to the theories discussed, Islamic finance gives more focus to real resources and economic activity rather than hoarding and speculating on money. Banks expected to participate in economic activities, productivity, enhancement of corporate governance fort its customers and risk sharing. While Islamic banks in the study area and other banks that have a window of Islamic products have issued various financial products in trying to reach to financially exclude Muslim population, some of these products are looked at doubtfully by the Muslims.

\section{Result and Discussion}

\subsection{Introduction}

This chapter presents analysis and findings of the study as set out in the research methodology. The results are presented on effect of Islamic banks on financial deepening amongst Muslims in Robe Town. The data was gathered exclusively from open and close ended questionnaire as the research instrument. The questionnaire was designed in line with the objectives of the study. To enhance quality of data obtained.

\subsubsection{Response Rate}

The studies were targeted to sample 384 respondents in collecting data with regard to the effect of Islamic banks on financial deepening amongst Ethiopia Muslims case study Robe Town. From the study, 379 out of 384 sampled respondents filled in and returned the questionnaire contributing to $99 \%$.This commendable response rate was made due to pandemic corona virus respondent's fear and stay at home.

Therefore most of the respondents were filled and returned the questionnaire 
Table 4:1: Response Rate

\begin{tabular}{|l|c|l|}
\hline Response & Frequency & Percentage \\
\hline Responded & 379 & 99 \\
\hline Not responded & 5 & 1 \\
\hline Total & 384 & 100 \\
\hline
\end{tabular}

Source: Researcher survey (2020)

\subsection{Respondents Information}

\subsubsection{Respondents Gender and Age}

The results of this study showed that mass of the respondents in the study area greater part were male with $73 \%$ and $27 \%$ of females.

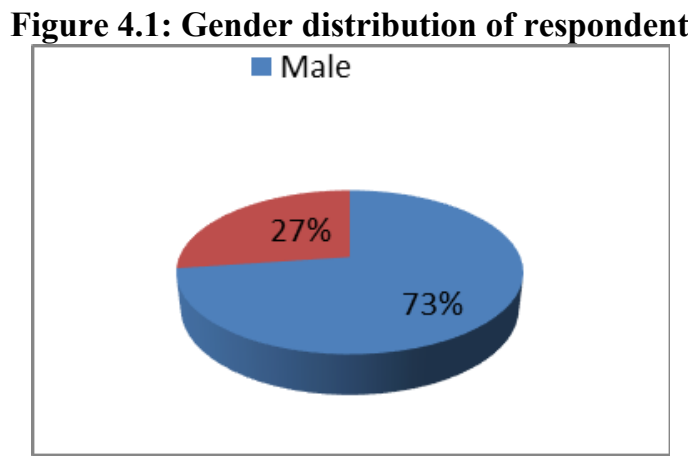

Source: Researcher survey (2020)

As table below showed that the highest number of sampled respondents was 54\% age group 35-49 years, while a further $41 \%$ of the age group was 25 to 34 years, $5 \%$ consisted of respondents above $65 y$ years, as the table below illustrates (Table 2)

Table 4.2 Age distribution of sampled respondents

\begin{tabular}{|l|l|l|}
\hline Age distribution & Frequency & Percent \\
\hline $25-34$ & 155 & 41 \\
\hline $35-49$ & 205 & 54 \\
\hline $65^{+}$ & 19 & 5 \\
\hline Total & 379 & 100 \\
\hline
\end{tabular}

Source: Researcher survey (2020)

\subsubsection{Current Employment}

The result of this study exposed that the percentage of self-employed, employed, retire and unemployed were $38 \%, 39 \%, 11 \%$ and $12 \%$ respectively (Figure 2 ).

Figure 4.2: Employment status of sampled respondents

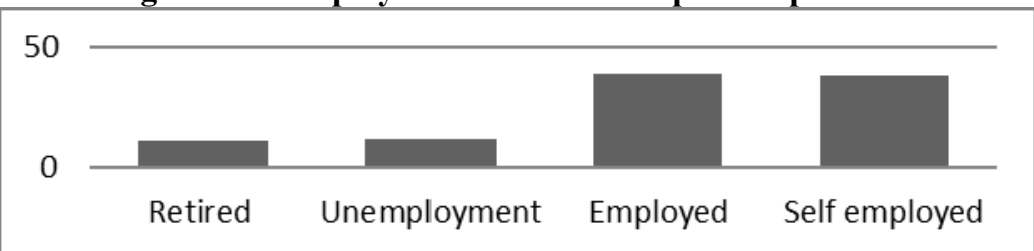

Source: Researcher survey (2020)

\subsubsection{Respondents Educational Qualifications}

Table 4 presents the educational status of the sampled respondents. Majority of respondents had a level IV education and the lowest education levels attained by sampled respondents were master level.

Table 4.3: Respondents education

\begin{tabular}{|l|l|l|}
\hline Education status & Frequency & Percentage \\
\hline Illiterate & 6 & 1.583 \\
\hline $10^{\text {th }}$ complete & 40 & 10.554 \\
\hline $12^{\text {th }}$ complete & 26 & 6.860 \\
\hline Diploma & 164 & 43.271 \\
Degree & 139 & 36.675 \\
\hline Masters & 4 & 1.055 \\
\hline Total & 379 & 100 \\
\hline
\end{tabular}

Source: Researcher survey (2020) 


\subsubsection{Monthly Income}

As the result showed that monthly income of the respondents were stated as follow (fig4.3)

Figure 4.3: Respondents income

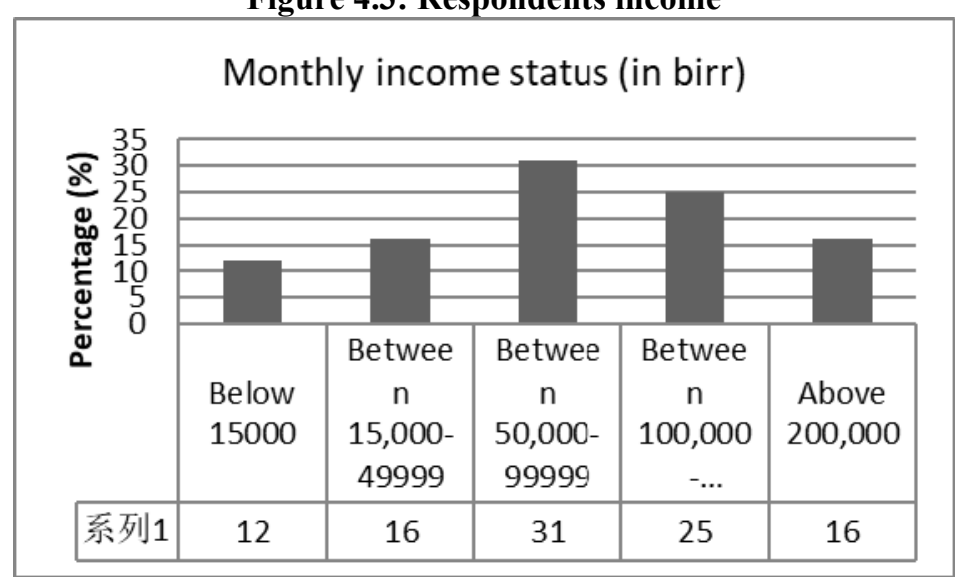

Source: Researcher survey (2020)

\subsection{Conventional Financial Services}

This section is intended to collect and analyze data on whether the respondents have financial products offered by conventional banks.

\subsubsection{Access to Conventional Financial Services}

In the study area Majority of the respondents had a savings account which the highest percentage of $43 \%$ followed by current account with a percentage of $32 \%, 25 \%$ did not have account. Generally respondent response showed that access to convectional financial service were saving account, current account and did not have account.4.3.2 Financial Products from Conventional Bank

The following financial products from conventional bank were used by the respondents $27 \%$ of financial product from conventional bank is personal loan, $21 \%$ of financial product from conventional bank is business loan and $52 \%$ of customers have not taken any loan. This revealed that most of the people (52\%) do not have access for financial product from convectional bank due to lack of financial product in Robe town like murabah, musharka and ijara which are not provided under the financial product of convectional bank while they are only used for saving.

Table 4.4: Respondents financial products

\begin{tabular}{|l|l|l|}
\hline & Frequency & Percent \\
\hline Personal loan & 103 & 27.17678 \\
\hline Business loan & 79 & 20.84433 \\
\hline None & 197 & 51.97889 \\
\hline Total & 379 & 100 \\
\hline
\end{tabular}

Source: Researcher survey (2020)

\subsubsection{Financial Products from Islamic Bank}

With regard to Financial Products from Islamic Bank about $66 \%$ of the sampled respondents had not taken any loan with any Islamic bank before, as the table below. These indicate that most of the Muslim society do not taken any loan due to strict rule and regulation and lack of awareness and Islamic bank itself had 6 month age in Robe town.

Table 4.5: Respondents Islamic bank products

\begin{tabular}{|l|l|l|}
\hline & Frequency & Percent \\
\hline Personal loan & 42 & 11 \\
\hline Business loan & 89 & 23 \\
\hline None & 249 & 66 \\
\hline Total & 379 & 100 \\
\hline
\end{tabular}

Source: Researcher survey (2020)

\subsubsection{Reasons Not Having Financial Products}

Majority of the respondents those sampled in the questioner were with $40 \%$ most of them think as they are the same, $32 \%$ of them due to rule and regulation of national bank and $28 \%$ of them did not know how to go about it, as the figure below illustrates. These studies indicate that most of the Muslim societies think as they are the same in terms of from where to where sources come. 
Table 4.6. Reasons not having financial products

\begin{tabular}{|l|l|l|}
\hline & Freq & Percent \\
\hline Most of them think as they are the same & 152 & 40 \\
\hline Lack of Rule and regulation & 121 & 32 \\
\hline Did not know how to go about it & 106 & 28 \\
\hline & 379 & 100 \\
\hline
\end{tabular}

Source: Researcher survey (2020)

\subsubsection{Financial Products with High Demand}

The result showed that Business financing schemes was the most important financial service needed on day today basis, as the figure below shows with $40 \%$ while Short-term islamic bankingloan had a $25 \%$ response money transfers had a response of $9 \%$, while savings scheme had 10\% none financial product had $16 \%$ as the figure below shows. According to Al nur Bank manager interview revealed that murabah is the most popular service in Robe town.

Table 4.7: Respondents Response on Financial Products with High Demand

\begin{tabular}{|l|l|l|}
\hline & Freq & Percent \\
\hline Business financing schemes & 156.6 & 40 \\
\hline Short-term islamic bankingloan & 94.75 & 25 \\
\hline money transfers & 34.11 & 9 \\
\hline savings scheme & 37.9 & 10 \\
\hline None & 60.64 & 16 \\
\hline
\end{tabular}

Source: Researcher survey (2020)

\subsection{Existing Shariah Compliant Financial Products}

This section is intended to collect and analyze data on whether the respondents have financial products offered by Islamic banks.

\subsubsection{Shariah Compliant Information Knowledge}

All the participant had information about the existing Shariah compliant financial products in Ethiopia before as the below table shows;

Table 4.8: Respondents knowledge on Shariah compliant

\begin{tabular}{|l|l|l|}
\hline & Frequency & Percent \\
\hline Yes & 379 & 100 \\
\hline
\end{tabular}

Source: Researcher survey (2020)

As table below $66 \%$ of respondents had a bank account with the institutions offering Shariah compliant financial products while 34 percent do not as the table shows. These indicate that most of Islamic societies have bank account with institutions offering shariah compliant financial product.

Table 4.9: Respondents with Shariah compliant bank accounts

\begin{tabular}{|l|l|l|}
\hline & Frequency & Percent \\
\hline Yes & 249 & 66 \\
\hline No & 130 & 34 \\
\hline Total & 379 & 100 \\
\hline
\end{tabular}

Source: Researcher survey (2020)

\subsubsection{Reasons Not Having Accounts With Shariah Compliant}

The main reason why the respondents in the study area did not have an account with any of the institutions providing Shariah compliant financial products was $40 \%$ who said they are not interested in their accounts, $60 \%$ said they think they are not any different that means they are similar.

Figure 4.4: Reasons Not Having Accounts with Shariah Compliant

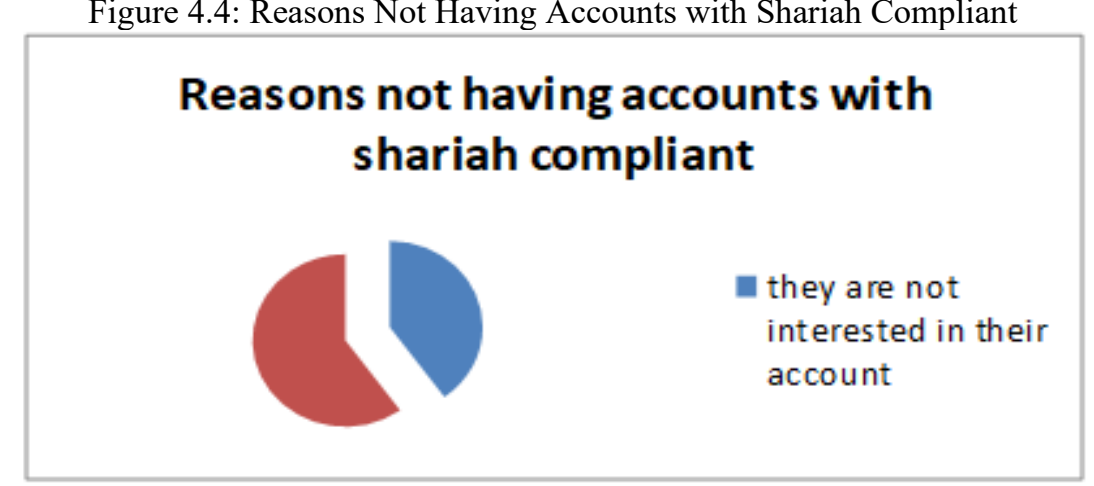

Source: Researcher survey (2020) 


\subsubsection{Mortgages Taken}

As the table below indicates out of the 379 respondents $22 \%$ took a conventional mortgage to Purchase property while $78 \%$ of them did not have mortgage loans. According Al nur manger interview mortgages loan did not given for government employee by using certificate as collateral due to restriction of regulation.

Table 4.10. Mortgages taken

\begin{tabular}{|l|l|l|}
\hline & Frequency & Percent \\
\hline Yes & 84 & 22 \\
\hline No & 295 & 78 \\
\hline Total & 379 & 100 \\
\hline
\end{tabular}

Source: Researcher survey (2020)

\subsection{Expectation from the Introduction of Islamic Finance in Ethiopia}

\subsubsection{Respondents Owning Businesses}

The respondents showed that $38 \%$ were not in own business, while $62 \%$ were in own business as the table below illustrates. Generally this indicates that most of the Muslim societies in robe town own the business.

Table 4.11: Respondents owning businesses

\begin{tabular}{|l|l|l|}
\hline & Frequency & Percent \\
\hline Yes & 236 & 62 \\
\hline No & 143 & 38 \\
\hline Total & 379 & 100 \\
\hline
\end{tabular}

Source: Researcher survey (2020)

4.5.2 Business Loan for Startup Business

$62 \%$ of the respondents revealed that did not take out a loan from any bank or any other institution when starting up the business $38 \%$ of the respondents indicate that took a loan. Generally these show that most of the Muslim society not accommodated in the service.

Table 4.12: Business loan for startup

\begin{tabular}{|l|l|l|}
\hline & Frequency & Percent \\
\hline No & 236 & 62 \\
\hline Yes & 143 & 38 \\
\hline Total & 379 & 100 \\
\hline
\end{tabular}

Source: Researcher survey (2020)

\subsubsection{Shariah Compliant Institutions Approached}

The figure below illustrates that $83 \%$ did not approach any of the institutions offering Shariah compliant financial products for raising finance for their business and a total of $17 \%$ approached Islamic banks.

Figure 4.5: Shariah compliant institutions approached

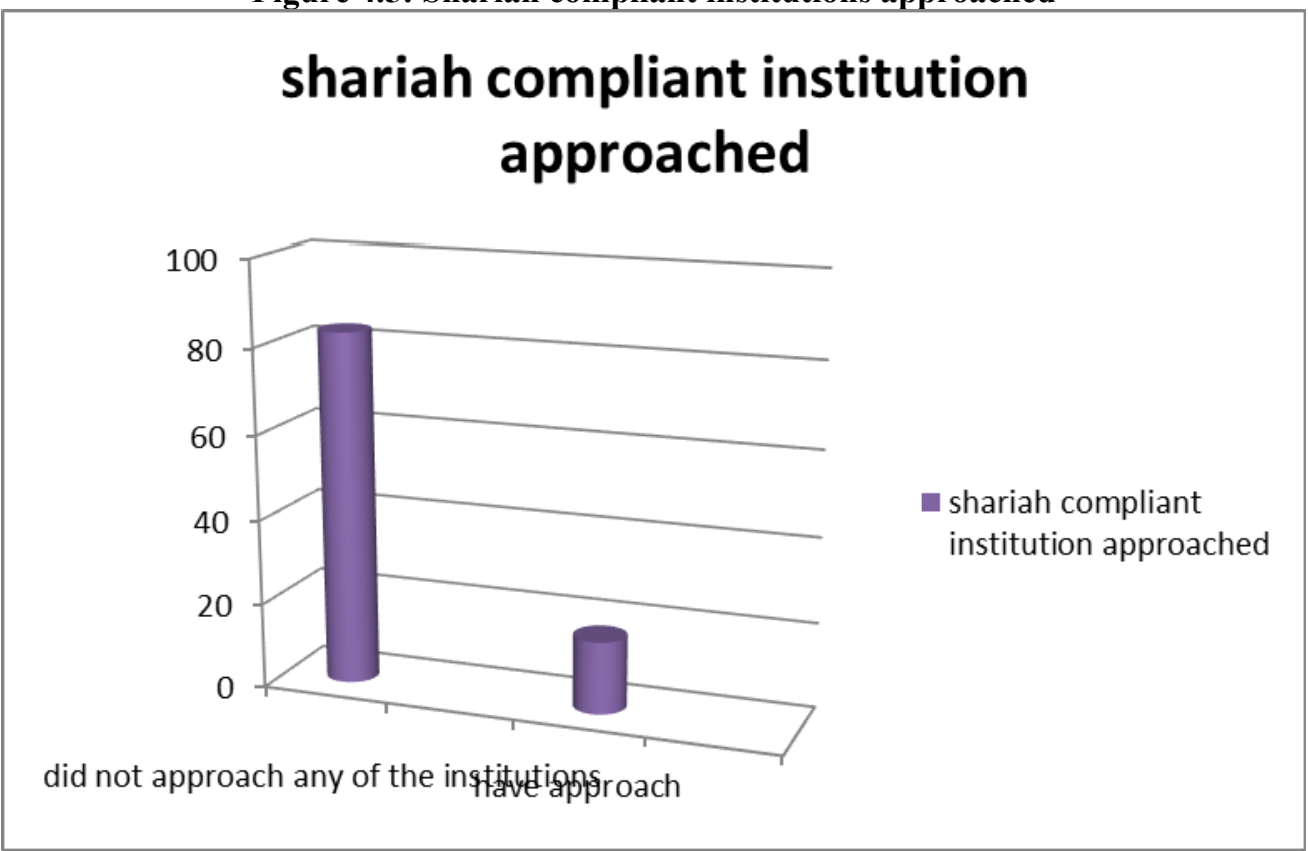

Source: Researcher survey (2020) 


\subsubsection{Reasons Not Approaching Shariah Compliant Institutions}

The reason why the respondents did not approach the institutions indicate that a total of $22 \%$ who did not need their help, $52 \%$ think they are not different from conventional banks while $26 \%$ gave reasons like strict policies in giving out their loans specially for government employees. The results show that most of them think that they are the same while performed by one head office at country level.

Table 4.13: Reasons not approaching the Shariah compliant institution

\begin{tabular}{|l|l|l|}
\hline & Frequency & Percent \\
\hline You did not need their help & 85 & 22 \\
\hline You think they are not different & 196 & 52 \\
\hline from conventional banks that provide through window & & \\
\hline Strict policies & 98 & 26 \\
\hline & 379 & 100 \\
\hline
\end{tabular}

Source: Researcher survey (2020)

\subsubsection{Shariah Compliant Institution Instructions}

As the respondents response The availability of suitable Shariah compliant business finance would help mostly in the expansion of the business with a response of $28 \%$ another $46 \%$ said it would help to improve lives of many Muslims 26\% said it would result in wealth creation among Muslims in the study area. These response shows that most of the Muslim societies believe shariah compliant institution improve lives of Muslim society. Table 4.14: Importance of Shariah compliant institutions

\begin{tabular}{|l|l|l|}
\hline & Frequency & Percent \\
\hline Expand business, leads to more profits & 106 & 28 \\
\hline Improve lives of many Muslims & 176 & 46 \\
\hline Result in wealth creation among Muslims & 97 & 26 \\
\hline Total & 379 & 100 \\
\hline
\end{tabular}

Source: Researcher survey (2020)

\subsection{Interview Analysis}

According to respondent response interview of different respondent the result indicate that, the availability of suitable Shariah compliant business finance has impact on your business strategy according to Al nuur Bank manager Muslim society in Robe Town needs more Murabah service while the bank has different strategy that not suitable for robe town Muslim society but offered by the bank which are Shariah compliant products such as ijara ,mudaraba and musharaka in Robe town but the most popular one is murabah. Banks expected to participate in economic activities, productivity, enhancement of corporate governance fort its customers and risk sharing. According to manager of commercial bank of Ethiopia Souf omer branch most of the current customers has not been accessing conventional banking services due to their faith while the bank has taken separate service giving of product rather than through window to improve financial deepening. Most of the people in Robe town are muslim due to this reason murabah service has been achieved so far Shariah compliant products on offer in Robe town .

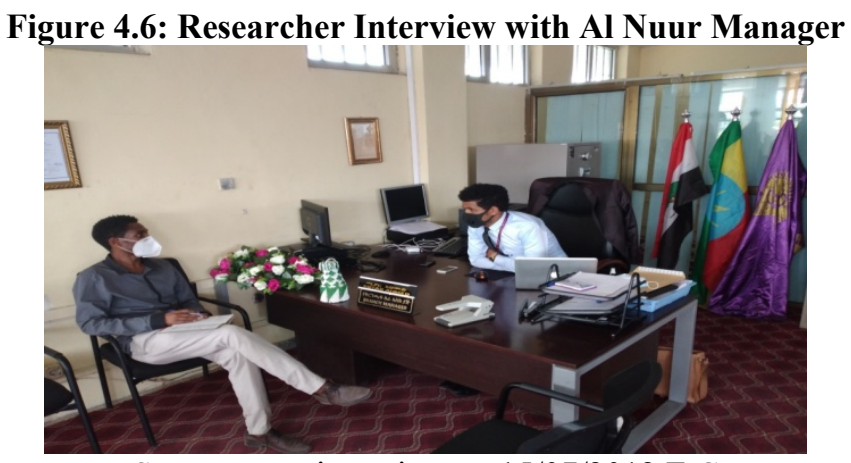

Source: own interview on 15/07/2012 E.C

\section{Conclusions and Recommendations}

\subsection{Introduction}

This chapter provides the summary of the findings from chapter four, and also it gives the conclusions and recommendations based on the finding related with objectives of the study. The objectives of this study were used to determine the effects of Islamic banks on financial deepening amongst Muslims case study Robe Town, to understand the overall socioeconomic structures as well as the banking behavior of Muslim community and their access to conventional finance prior to the introduction of Islamic finance Ethiopia, To understand banking 
and other micro-financial services and home-financing facilities employed by these communities.

\subsection{Summary of the Findings}

This section summarizes the main research findings intending to present some policy recommendations. The main research findings related with research objectives here is worth mentioning that form part of my own empirical results. According to this research, $78 \%$ of the sampled respondents showed have not taken any loan from the Islamic banks, majority of the respondents (52\%) thought they are not different from other conventional banks and that they did not want to deal in interest. Others gave other reasons like bureaucracy and strict policies and requirements in giving out loans; others said the Islamic banks have poor marketing strategies in informing customers about their products. Majority of the respondents $(66 \%)$ of the sampled has a bank account with the Islamic banks or banks offering Islamic products but they have not benefitted from any of their products.

\subsection{Conclusions}

Islamic banking is continuing to expand as a viable financial institution in areas with Muslim populations across the world, yet its effect on economic growth and the deepening of financial systems was previously undetermined. This paper attempted to add to the literature on Islamic banks by investigating effect of Islamic banks on financial deepening amongst Muslims case study Robe Town. Muslims in Robe Town appreciate the need to have financial products that comply with their faith; they have strong need for financial support which is yet to be satisfied by the available Islamic banks in Robe Town.

\subsection{Recommendations}

From the results of this study, the following recommendations were forwarded to improve the performance of Islamic banking and finance institutions. Here it is worth mentioning that the performance of Islamic banking and finance from a socio-economic perspective is a multifaceted and complicated issue with many reasons working behind as it has previously been mentioned. Among these reasons are; disbelief, availability of small range of the products, extra marginal cost of the products, less access of the customers to these products, little knowledge and less awareness of the people about Islamic finance and these products, etc. The study further recommends change in financial regulations and improves existing regulation by national bank of Ethiopia, like allowing the banks to have joint venture with borrowers, allow the banks to share in profits, permit loan government employee by certificate as collateral in convectional bank and loss of borrowers' businesses that they finance.

\section{5 .Suggestions for Further Research}

Every study cannot be necessarily free from limitations to some point. Accordingly, there are some limitations in present study. At first, it focused only on effect of Islamic bank on financial deepening in case of Robe Town. Thus, the findings of this study can be generalized for Muslim community in Robe Town but it is difficult to generalize these findings about all Muslim community at others Town, City and national level. Further researchers can also include other some further research areas where future researcher can work to improve the results contribute to bring a positive change and the correlation between financial and social performance of Islamic banks can further be, studied with more specific areas and wider resources for research. Although we have very limited research discussing the financial and economic aspect of Islamic banking Robe town, but the social role of this newly banking system has almost been neglected and needs to be explored in more specific way.

\section{References}

Abdul Jabbar Karimi (n.a); Challenges Facing Islamic banks. Unpublished report.

Agu, Chukwu, et al. (2008) Toda and Yamamoto causality tests between bank-based financial deepening and economic growth in Nigeria. European Journal of Social Sciences.

Alemu, D (2015) Factors Affecting Customers" to Use Islamic bankingBanking in Ethiopia:Addis Abebe Ethiopia.

Al-nuur Manager Interview. (2012).on 15/17/2012.E.C

Ariff, M. (1988) 'Islamic banking', Asian-pacific Economic literature, vol.2 No.2, pp 46-62.

Fisher, S (2001) The Importance of Financial Markets in Economic Growth: Memo, The Brazilian Mercantile and Futures Exchange, Citigroup, Campos do Jordao. Brazil .

Hanlon, M (2005) Islamic Bank of Britain Offers Helping Hand to the Financially Excluded. The Islamic Bank of Britain Press Release Archives.

Ifeanyi ,Nwanna et al.(2016) The Effect of Financial Deepening on Economic Growth. Nigeria: Nnamdi Azikiwe University.

IMF Working Paper African Department (2015) Is Islamic Banking Good for Growth? 
Jalilian, H and Kirkpatrick, C (2005); Does Financial Development Contribute to Poverty Reduction. The Journal of Develoment Studies Volume 41, Iissue 4, 2005.

Mohammed, EI and IMF (2005); Islamic Finance Gears up, Finance \& Development.

Mustafa Ali. (2013), effect of islamic banks on financial deepening amongst robe town muslims.

Nzotta and Okereke (2009); Financial Deepening and Economic Development in Nigeria: An Empirical Investigation African Journal of Accounting, Economics, Finance and Banking Research, 5(5), 52-66.

Policy Analysis on Ethiopia Interest Free Banking Directive (2017); impact of islamic banking on the financial performance of conventional banks offering islamic banking products . kenya. Policy Analysis on Ethiopia Interest Free Banking Directive

Robe town Administration and CBE (2020); government employee, service sector and trader data. Robe. Robe town Administration and $\mathrm{CBE}$

Sahoo. S (2013) Financial Structures and Economic Development in India: An Empirical Evaluation, RBI Working Paper No.02, Department of Economic and Policy Research, Mumbai .Reserve Bank of India.

Sami ,Alexander et al . Can Islamic Banking Increase Financial Inclusion?

Shaw, E, (1973), Financial Deepening in Economic Development. Oxford University Press.

Tsion. S. (2015), Challenges and opportunities of islamic banking in Ethiopia,Addis Abebe,Ethiopia.

Yudistira D. (2003), 'Efficiency of Islamic banks; an empirical analysis of 18 banks', finance no. 0406007, Econ UPA. 